\title{
PELAKSANAAN HUKUM WARIS DI MASYARAKAT KARO MUSLIM SUMATERA UTARA
}

\author{
Azhari Akmal Tarigan \\ IAIN Sumatera Utara \\ Jl. Williem Iskandar Pasar V, Medan Estate, Sumatera Utara \\ E-mail: azhariakmaltarigan@yahoo.co.id
}

\begin{abstract}
Implementation of Inheritance Law of the Muslim Karo in North Sumatra. So far, Indonesia has not managed the codification and unification of a national inheritance law. Among the factors is the difficulty of codifying inheritance laws by reason of the diversity of the legal system that governs family matters of the Indonesian people, including inheritance laws. This study examines the way of implementing the inheritance law in Karo Muslim society, North Sumatra. This study focuses on the models of estate distribution to girls and widows. The article concludes that the Muslim Karo people still use customary law to resolve matters relating to inheritance disputes. Customary law that is used is experiencing dynamics or shifts. This happens without giving rise to tension let alone any disturbances within Karo Muslim community itself.
\end{abstract}

Keywords: inheritance law, custom, heir, daughter, widow

Abstrak. Pelaksanaan Hukum Waris di Masyarakat Karo Muslim Sumatera Utara. Sampai saat ini Indonesia belum berhasil melakukan kodifikasi dan unifikasi hukum waris nasional. Diantara faktor sulitnya melakukan pengkodifikasian hukum waris karena beragamnya sistem hukum yang mengatur persoalan keluarga, termasuk hukum waris, masyarakat Indonesia. Studi ini mengkaji bagaimana pelaksanaan hukum waris masyarakat Karo Muslim Sumatera Utara. Studi ini menitikberatkan pada model pembagian harta waris kepada anak perempuan dan janda. Artikel ini menyimpulkan bahwa masyarakat Karo Muslim masih menggunakan hukum adat dalam menyelesaikan hal-hal yang berkaitan dengan sengketa waris. Hukum adat yang dipakai adalah hukum adat yang mengalami dinamisasi atau pergeseran. Hal ini terjadi tanpa menimbulkan ketegangan apalagi goncangan di masyarakat Karo Muslim itu sendiri.

Kata Kunci: hukum waris, adat, ahli waris, anak perempuan, janda

\section{Pendahuluan}

Pranata hukum waris merupakan salah unsur yang penting dalam kehidupan masyarakat, terlebih pada masyarakat adat ${ }^{1}$, karena implikasinya yang bersifat langsung terhadap kelanggengan sistem sosial, baik pada tataran keluarga, karib kerabat maupun masyarakat pada umumnya. Begitu pentingnya pranata warisan ini, sehingga hampir seluruh masyarakat adat memiliki sistem kewarisan tersendiri yang berbeda antara satu

Naskah diterima: 10 Maret 2014, direvisi: 1 April 2014, disetujui untuk terbit: 20 Mei 2014.

${ }^{1}$ Van Vollenhoven telah menyusun wilayah hukum adat. Suatu daerah yang garis-garis besar corak dan sifat hukum adatnya seragam oleh van Vollenhoven disebut rechtskring (lingkaran hukum).Tiap-tiap lingkaran hukum itu dapat dibagi lagi ke dalam kubukan-kubukan hukum. Adapun wilayah lingkaran dan kubukan hukum adat tersebut adalah: (1) Aceh (Aceh Besar, Pantai Barat Aceh, Singkel, Simeuleue). (2) Tanah Gayo, Alas, dan Batak (Tanah Gayo, Tanah Alas, Tanah Batak (Tapanuli), Tapanuli Utara, Batak Pak-Pak, Batak Karo, Batak Simalungun, Batak Toba (Samosir, Balige, Lagubati, Lumban Julu), Tapanuli Selatan, Padang Lawas, Angkola, Mandailing (Sayurmatinggi), dan Nias. (3) Daerah Minangkabau (Padang, Agam, Tanah Datar, Lima Puluh Kota, Tanah Kampar) dan Mentawai. (4) Sumatera Selatan dengan lainnya. ${ }^{2}$

Pada masyarakat Minang, misalnya, dengan sistem kekerabatan yang matrilinear, ${ }^{3}$ yang berhak mendapat harta warisan (harta pusaka tinggi) adalah

(Bengkulu -Rejang-, Lampung -Abung, Peminggir, Pubian, dan lain-lain-, Palembang (Anak Lakitan dan lain-lain), Jambi (Batin dan Penghulu), dan Enggano. (5) Daerah Melayu. (6) Bangka Belitung. (7) Kalimantan (Dayak). (8) Minahasa. (9) Jawa Barat, Jawa Timur, Jawa Tengah, dan seterusnya. Jika direkapitulasi, di Pulau Sumatera terdapat 49 wilayah hukum adat, Jawa 7, Kalimantan 73, Sulawesi 117, Nusa Tenggara 30, Maluku \& Ambon 41 dan Irian Jaya 49. Soerjono Soekanto dan Soleman b. Taneko, Hukum Adat Indonesia, (Jakarta: Rajawali Press, 1986), h. 20-40. Soleman B. Taneko, Hukum Adat: Suatu Pengantar Awal dan Prediksi Masa Mendatang, (Bandung: Eresco, 1987), h. 45-46. John Ball membuatnya lebih ringkas, yaitu terdiri atas 19 wilayah area hukum adat Indonesia. Aceh ditempatkan sendiri. Gayo, Alas, dan Batak lands menjadi satu. Demikian juga dengan Minangkabau Territory dan sebagainya. John Ball, Indonesian Law at the Crossroads: Commentary and Materials, (Sydeny: Oughtershaw, 1996), h. 126.

${ }^{2}$ Mengenai karakter hukum waris adat masing-masing daerah lihat Hilman Hadikusuma, Hukum Waris Adat, (Bandung: Alumni, 2003), h. 126-128.

${ }^{3}$ Setidaknya ada tiga macam sistem kekeluargaan yang selanjutnya berpengaruh pada sistem kewarisan yang dianut, yaitu: (1) Patrilineal 
anak perempuan dan anggota keluarga perempuan lainnya. Sedangkan anak laki-laki tidak mendapatkan apa-apa. ${ }^{4}$ Pada masyarakat Jawa dengan sistem kekerabatannya yang parental (bilateral), hak mewarisi sama-sama dimiliki anak laki-laki dan perempuan sehingga tidak ada perbedaan di antara keduanya. ${ }^{5}$

Selanjutnya pada masyarakat Batak Toba dengan sistem kekerabatannya yang patrilinear, yang berhak mewarisi adalah anak laki-laki. Sedangkan anak perempuan tidak dipandang sebagai ahli waris. ${ }^{6}$

Masyarakat Karo, sebagaimana masyarakat Batak lainnya, juga menganut sistem kekerabatan patrilinear. Hak mewarisi terdapat pada anak laki-laki, sedangkan anak perempuan tidak mendapatkan harta waris dari orang tuanya. ${ }^{7}$ Dalam pandangan masyarakat Karo, anak perempuan jika kelak menikah akan menjadi bagian dari keluarga laki-laki dan ia akan mendapatkan harta dari suaminya. ${ }^{8}$

Sistem kekerabatan patrilineal yang dianut masyarakat Karo telah menempatkan laki-laki sebagai pihak yang "superior" dibanding dengan perempuan. Namun dalam hal-hal tertentu, pihak perempuan bisa saja mendapatkan harta dari keluarganya, misalnya dari

yang menimbulkan kesatuan-kesatuan kekeluargaan yang besar-besar seperti clan dan marga, dimana setiap orang itu selalu menghubungkan dirinya hanya kepada ayahnya. (2) Matrilineal yang juga menimbulkan kesatuan-kesatuan kekeluargaan yang besar-besar, seperti clan dan suku, dimana setiap orang selalu menghubungkan dirinya hanya kepada ibunya dan karena itu termasuk ke dalam clan suku ibunya. (3) Parental atau bilateral yang mungkin menimbulkan kesatuan-kesatuan kekeluargaan yang besar-besar seperti tribe dan rumpun, dimana setiap orang itu menghubungkan dirinya dalam hal keturunan, baik kepada ibunya atau ayahnya. Hazairin, Hukum Kewarisan Bilateral Menurut Qur'an dan Hadith, (Jakarta: Tintamas, 1990), Cet: VII, h. 11.

${ }^{4}$ Amir Syarifuddin, Pelaksanaan Hukum Kewarisan Islam dalam Lingkungan Adat Minangkabau, (Jakarta: Gunung Agung, 1982), h. 260-269 dan Yaswirman, Hukum Keluarga Adat dan Islam: Analisis Sejarah, Karakteristik, dan Prospeknya dalam Masyarakat Matrilineal Minangkabau, (Padang: Andalas University Press, 2006), h. 216-240.

5 Otje Salman Soemadiningrat, Rekonseptualisasi Hukum Adat Kontemporer, (Bandung: Alumni,2002), h. 197-199.

${ }^{6}$ Ketentuan pokok dalam hukum warisan adat Batak Toba adalah bahwa anak laki-laki merupakan pewaris harta peninggalan bapaknya. Dalam arti bahwa jika ada anak laki-laki, merekalah yang menjadi ahli waris harta peninggalan bapaknya. Memang dimungkinkan untuk memberikan sebagian harta warisan kepada affina, tetapi mereka bukanlah termasuk ahli waris, sehingga mereka juga tidak bertanggung jawab atas hutang orang tua yang meninggal, walaupun mereka memang dapat memberi sumbangan guna pelunasannnya. J.C. Vergouwen, Masyarakat dan Hukum Adat Batak Toba, (Yogyakarta: LKiS, 2004), h. 377 dan Felix Sitorus, "Hak Waris Janda dan Anak Perempuan Batak", dalam Hukum dan Kemajemukan Budaya, editor E.K.M.Masinambow, (Jakarta: Yayasan Obor Indonesia, 2000), h. 290-298.

7 Djaja S. Meliala dan Aswin Peranginangin, Hukum Perdata Adat Karo dalam Rangka Pembentukan Hukum Nasional, (Bandung: Tarsito, 1979), h. 54.

${ }^{8}$ Djaja S. Meliala dan Aswin Peranginangin, Hukum Perdata Adat Karo dalam Rangka Pembentukan Hukum Nasional, h. 65. orang tua dan saudara, namun tetap tidak dipandang sebagai ahli waris. Misalnya, jika seorang anak perempuan mengalami kesulitan di dalam hidupnya, maka ia dapat meminta bantuan kepada saudaranya yang laki-laki. Biasanya pihak kalimbubu akan memberinya harta yang disebut dengan keleng ate, artinya bantuan atas dasar kasih sayang. ${ }^{9}$

Beberapa ungkapan yang dikenal pada masyarakat Karo di bawah ini akan menjelaskan bagaimana posisi perempuan Karo. Ada ungkapan dilaki ngenca berhak (slechts zoona zijn gerechtigd), artinya hanya anak lakilaki yang berhak. Lalu ada juga ungkapan dilaki ngenca ibas pembagian (hanya anak laki-laki yang mendapat hak dari pembagian harta warisan), sidiberu la kenan (anak perempuan tidak mendapat bagian), diberu la banci erban taka (perempuan tidak bisa menetapkan porsi), diberu la der kaipe (anak perempuan tanpa perolehan sesuatu apapun). ${ }^{10}$

Jika anak perempuan tidak mendapatkan harta waris dari orang tuanya, perempuan Karo yang berstatus janda juga mengalami nasib yang sama. Ia sama sekali tidak berhak mendapatkan harta warisan dari suaminya. Ia hanya diberikan hak untuk mengelola dan menikmati hasil harta peninggalan suaminya seperti sawah atau kebun sepanjang belum menikah dengan pria lain. Jika ia menikah kembali, maka haknya untuk mengelola dan mengambil manfaat dari harta suaminya menjadi hilang. ${ }^{11}$

Lalu persoalan yang tidak kalah pentingnya adalah bagaimana dengan kenyataan bahwa sebagian masyarakat Karo telah memeluk agama Islam. Sebagai sebuah agama yang kâmil (sempurna) dan syumûl (melingkupi segala hal), Islam juga memiliki sistem hukum waris tersendiri yang dikonstruksi berdasarkan ayat-ayat suci Alquran dan Hadis. Dengan demikian, masyarakat Karo Muslim, dalam kedudukannya sebagai orang Karo yang tunduk pada adat, sebagai Muslim yang tunduk pada syariat dan sebagai warga negara yang dituntut tunduk pada hukum negara, dihadapkan pada tiga sistem hukum, yaitu hukum adat, hukum Islam dan hukum nasional. Tidak tertutup kemungkinan antara ketiga sistem hukum tersebut akan saling berkompetisi untuk menjadi sistem hukum yang

${ }^{9}$ Djaja S. Meliala dan Aswin Peranginangin, Hukum Perdata Adat Karo dalam Rangka Pembentukan Hukum Nasional, h. 65.

${ }^{10}$ Herman Slaats dan Karen Portier, Traditional Decision Making and Law, (Yogyakarta: Gadjah Mada University Press, 1992), h. 113 dan H.K.Kueteh Sembiring, "Perkembangan Hukum Adat Etnis Batak Dalam Pembagian Harta Warisan”, Laporan Penulisan Fakultas Hukum Universitas Sumatera Utara, 1990, h.74-75

${ }^{11}$ Djaja S. Meliala dan Aswin Peranginangin, Hukum Perdata AdatKaro dalam Rangka Pembentukan Hukum Nasional, h. 56. 
diterima masyarakat. Inilah yang disebut oleh John R Bowen sebagai competing norm. ${ }^{12}$

Pertanyaan yang menarik untuk diajukan adalah bagaimana sikap dan keputusan yang diambil masyarakat Karo Muslim dalam menyelesaikan persoalan pembagian harta warisan, bagaimana pula dengan pilihan hukum masyarakat Karo Muslim, apakah mereka tetap memilih hukum adat sebagai hukum yang hidup atau hukum Islam sebagai hukum agama yang bersumber dari wahyu, atau malah mereka menyerahkan persoalannya ke pengadilan negeri atau pengadilan agama.

Studi ini ini bukanlah studi pertama yang membahas persoalan hukum waris pada masyarakat Karo. Selain masalah kewarisan beda agama (kewarisan beda iman), persoalan kedudukan anak perempuan dan janda dalam sistem hukum waris adat Karo sudah kerap dibahas para penulis sebelumnya. Namun pendekatan yang dipakai sebagian penulis adalah pendekatan kuantitatif. Akibatnya, kajian terhadap hukum waris Karo terkesan hanya berada di permukaan. Penulisan terdahulu belum sepenuhnya berhasil menyingkap alasan atau argumentasi yang mendasari pilihan-pilihan hukum mereka. Disamping itu, penulisan terdahulu tidak sepenuhnya berhasil mengungkap alasan serta nilainilai yang mendasari perilaku dan sikap masyarakat Karo dalam berinteraksi dengan hukum. Walaupun demikian, penulisan terdahulu tetap penting dan berguna untuk mendukung penulisan ini.

\section{Pelaksanaan Hukum Waris di Kabupaten Karo}

Studi ini menunjukkan bahwa masyarakat Karo, bahkan yang sudah memeluk Islam sekalipun, ternyata masih menggunakan hukum adat untuk menyelesaikan persoalan-persoalan yang mereka hadapi, termasuk dalam bidang waris. Ketika penulis menanyakan hukum manakah yang digunakan untuk menyelesaikan pembagian harta waris, tanpa ada keraguan sedikit pun para informan menjawab hukum adat. Ketika pertanyaan ini dilanjutkan, mengapa harus hukum adat dan mengapa tidak hukum Islam? Jawaban yang dikemukakan informan sangat sederhana dan tegas. Umumnya para informan menyatakan bahwa hukum adatlah yang pertama hadir di Tanah Karo, lalu kemudian Islam datang dengan pranata hukumnya. Artinya, sejak lama mereka telah tunduk pada hukum adat.

Dalam kasus pembagian harta waris bagi anak

12 John Bowen, Islam, Law, and Equality in Indonesia: An Anthropolgy of Public Reasoning, (London: Cambridge University Press, 2003), h. 5. perempuan, misalnya, hukum adat Karo dengan tegas menyebutkan bahwa perempuan, baik dalam statusnya sebagai anak ataupun janda tidak disebut sebagai ahli waris dan karenanya tidak mendapatkan bagian dari harta waris. Walaupun dalam kasus-kasus tertentu, ada anak perempuan yang mendapatkan harta waris, itu bukan karena kapasitas mereka sebagai ahli waris. Mereka menerima harta waris itu karena semata-mata pemberian saudaranya yang disebut dengan pemberian kelang ate.

Menurut hukum Islam, anak perempuan dan janda tidak saja diakui sebagai ahli waris, namun lebih dari itu, ajaran agama juga menetapkan porsi bagian untuk mereka berdua. Ketentuan Alquran yang menempatkan anak perempuan dan janda sebagai ahli waris sesungguhnya adalah sebuah perubahan radikal yang ditawarkan Alquran kepada masyarakat Arab yang menganut kekerabatan patrilineal. ${ }^{13}$ Jangankan menjadikan anak perempuan dan janda sebagai ahli waris, hukum adat Karo malah menempatkan anak perempuan sebagai "makhluk yang tidak dapat memberikan kontribusi apapun, baik dalam konteks kehidupan keluarga atau kesukuan”. Karena dipandang tidak berharga itulah maka anak perempuan tidak akan mendapatkan apapun dari harta orang tuanya. Terlebih lagi janda yang ditempatkan posisinya sama dengan "harta-tirkah" yang dapat diwarisi.

Pada gilirannya, Alquran hadir dengan menetapkan anak perempuan dan janda sebagai ashhâab al-furûdh

${ }^{13}$ Bangsa Arab membolehkan praktik poligami tanpa batasan maksimum dan tidak memperkenankan pembatasan jumlah istri. Ini merupakan spirit sistem paternalisme yang dianut oleh suku-suku nomadeni secara umum dan meniscayakan komposisi rumah tangga patriarki yang terdiri atas laki-laki sebagai poros, lalu sejumlah istri merdeka, ditambah budak-budak sariyyah (yang boleh disetubuhi secara bebas tanpa ikatan pernikahan). Dalam masyarakat patriarki ini, suami disebut dengan ba'al (tuan) istri. Ba'al juga berarti majikan atau pemilik. Kata ini sering digunakan dalam relasi perkawinan. Kata kuncinya adalah perkawinan bagi mereka dipahami sebagai kepemilikian (tamalluk). Istilah ba'al juga menyimbolkan poros otoritas tertinggi yang dinikmati oleh suami dalam masyarakat tribal. Dalam tradisi keluarga Arab, ia adalah pemilik istri, tuan, dan majikannya. Dialah yang memberi rezeki (nafka hidup) kepada istrinya dengan jalan berdagang atau paling sering justru dengan jalan merampok dan merampas. Makna positifnya adalah suami atau bajal juga menjadi pelindung dan pembela (kehormatan) istri ketika suku dan keluarganya diserang oleh suku lain. Oleh sebab itulah istri juga disebut dengan "haram" yang mengandung arti sesuatu yang dipertahankan atau dilindungi. Kendati kedatangan Islam tidak serta merta membuat kedudukan perempuan sama dengan laki-laki, tetapi setidaknya perempuan yang semula dipandang tidak bernilai telah diberi nilai separoh dari nilai laki-laki. Penting dicatat, menurut hemat penulis, hal ini bukan tujuan Alquran yang sesungguhnya. Akan tetapi karena Alquran menempuh cara yang gradual (tadarruj) untuk mengangkat posisi perempuan, apa yang ditawarkan Alquran sebenarnya sangat radikal dan progresif. Lihat lebih luas ulasan yang menarik dari Khalil Abdul Karim, Syariah: Sejarah Perkelahian Pemaknaan, diterjemahkan oleh Kamran As'ad, (Yogyakarta: LkiS, 2003), h. 33-46. 
dengan porsi tertentu. Anak perempuan berpeluang mendapatkan bagian harta, misalnya $1 / 2$ jika sendiri, 2/3 jika berbilang dan mendapatkan 1 bagian dari dua bagian anak laki-laki jika mereka bersama-sama sebagai ahli waris. Sedangkan janda memiliki kemungkinan untuk memperoleh $1 / 4$ jika pewaris tidak memiliki anak atau $1 / 8$ jika pewaris memiliki anak. ${ }^{14}$ Bahkan di dalam yurisprudensi Mahkamah Agung dan Kompilasi Hukum Islam, janda berhak untuk mendapatkan 1/2 dari harta bersama yang ditinggalkan suaminya. ${ }^{15}$

Sedangkan ahli waris yang lain, baik dalam konteks dzawî al-furûdh atau asabat, ketentuannya telah ditetapkan Allah Swt. di dalam Alquran dan Hadis Nabi Muhammad Saw. Beranjak dari pemahaman ayatayat inilah, para ulama menetapkan klasifikasi ahli waris kepada asabat, dzawî al-furûdh dan dzawî al-arhâam. ${ }^{16}$

Demikian juga hukum negara, sebagaimana terlihat

${ }^{14}$ Keberadaan anak perempuan dan janda sebagai ahli waris dan mendapatkan porsi tertentu (furûdh al-muqaddarah) terdapat pada Q.s. al-Nisâ'[4]: 11 dan 12. Muhammad 'Alî al-Shâbûnî, Al-Mawârits fì al-Syarî'ah al-Islâmiyyah fî Dhaw'I al-Kitâb wa al-Sunnah, (Madinah: Dâr al- Shâbûnî, 2002), h. 42-44; Amir Syarifuddin, Hukum Kewarisan Islam, (Jakarta:Prenada Media, 2004), h. 40-41 dan Sajuti Thalib, Hukum Kewarisan Islam di Indonesia, (Jakarta: Sinar Grafika, 2008), Cet. VIII, h. 117-118 dan 139-140.

${ }^{15}$ Dalam hukum adat, harta benda yang dimiliki oleh suami dan istri dapat dibedakan ke dalam dua kategori yang umum, yaitu: (1) Harta yang diperoleh sebelum perkawinan. (2) Harta benda yang didapat setelah perkawinan. Dalam masyarakat, baik yang matriarchal maupun patriarchal, kategori ini diakui dalam hukum perkawinan yang membahas masalah harta bersama, utamanya pasal 35 hingga 37 UU No. 1 Tahun 1974. Dalam peraturan tersebut, harta bawaan (harta pribadi yang dibawa ke dalam perkawinan) digunakan untuk merujuk pada tipe pertama, sedang harta bersama digunakan untuk tipe kedua. Dari sisi hukum Islam, baik ahli hukum kelompok Syâf'iyyah maupun para ahli hukum lain yang mewakili mazhab-mazhabnya tidak satu pun yang membahas topik tentang harta bersama dalam perkawinan ini sebagaimana yang dipahami di dalam hukum adat. Namun kalau dilihat dari sisi teknisnya, kepemilikan harta secara bersamaan antara suami dan istri dalam kehidupan perkawinan tersebut dapat dipersamakan dengan bentuk kerja sama (syirkah) yang lain yang secara umum telah dibahas oleh para ahli hukum Islam, walaupun para ahli fikih membahasnya tidak dalam konteks pernikahan. Ratno Lukito, Pergumulan antara Hukum Islam dan Hukum Adat di Indonesia, (Jakarta: INIS, 1998), h. 82-85. Lihat kajian ringkasnya pada Ratno Lukito, "Pergumulan Hukum Islam dan Adat di Indonesia", dalam, Dody S. Truna dan Ismatu Ropi (penyunting), Pranata Islam di Indonesia: Pergulatan Sosial, Politik, Hukum, dan Pendidikan, (Jakarta: Logos, 2002), h. 78-79. Kajian tentang harta bersama lihat juga, Abdul Manan, Aneka Masalah Hukum Perdata Islam di Indonesia, (Jakarta: Kencana Prenada, 2008), h. 103-129.

16 Dalam sistem kewarisan Suni, dikenal tiga kelompok ahli waris, ashhâb al-furûdh (dzawî al-furûdh atau ahli waris yang sudah ditentukan Alquran), dzawî al-arhâm (ahli waris yang ditarik dari garis ibu) dan asabat (ahli waris yang ditarik dari garis Bapak). Sistem waris Syiah hanya mengenal pembagian $d z a w \hat{\imath}$ al-furûdh dan $d z a w \hat{\imath} a l-$ qarâbah. Umumnya ada tiga martabat (tingkatan), yaitu (1) Martabat I, terdiri atas ibu, bapak, dan anak terus ke bawah. (2) Martabat II adalah saudara laki-laki dan perempuan terus ke bawah, kakek terus ke atas, nenek terus ke atas. (3) Martabat III adalah paman dan bibi dari bapak, paman dan bibi dari ibu, dan anak-anak mereka. Ketentuannya pada putusan Mahkamah Agung tahun 1961 yang menetapkan anak laki-laki dan perempuan sebagai ahli waris yang memiliki kedudukan yang sama. Implikasinya, anak perempuan harus mendapat bagian yang sama sebagaimana anak laki-laki. Ternyata di sebagian masyarakat Indonesia, menempatkan anakanak laki dan perempuan sebagai ahli waris telah menjadi kesadaran batin masyarakat sebagaimana terdapat pada masyarakat adat yang menganut sistem kekerabatan bilateral atau parental.

Persoalan tidak ditempatkannya anak perempuan sebagai ahli waris sebagaimana yang berlaku di Tanah Karo, sempat mencuat dan menjadi persoalan nasional ketika para pihak yang bersengketa mengajukan perkaranya ke Pengadilan Negeri Kabanjahe, Pengadilan Tinggi sampai kasasi ke Mahkamah Agung. Akhirnya, pada tanggal 23 Oktober 1961 keluarlah keputusan Mahkamah Agung No. 179/K/Sip/1961 yang menolak kasasi yang diajukan penggugat. ${ }^{17}$ Mahkamah Agung memutuskan bahwa anak perempuan (dalam gugatan tersebut) memiliki kedudukan yang sama dengan anak laki-laki dalam hal mewarisi harta dari kedua orang tuanya. ${ }^{18}$

Pada intinya, putusan tersebut menyebutkan bahwa berdasarkan rasa perikemanusiaan dan keadilan umum dan atas hakikat persamaan hak antara laki-laki dengan perempuan, sekaligus mempertimbangkan hukum yang hidup di seluruh Indonesia, bahwa anak perempuan, sebagaimana anak laki-laki, harus diposisikan sebagai ahli waris dan memiliki kedudukan yang sama. Intinya, anak perempuan juga berhak mewarisi harta orang tuanya. ${ }^{19}$

adalah kelompok I dapat menyisihkan kelompok di bawahnya. Disamping itu, masing-masing dapat menggantikan tempat dan kedudukan jika pada satu tempat tidak ada ahli waris yang semestinya. Sedangkan dalam perspektif Hazairin, kelompok ahli waris terdiri dari dzawî al-furûdh, dzawî al-qarâbah dan mawâlî (ahli waris pengganti). Hazairin mengenal istilah keutamaan, misalnya, anak laki-laki dan anak perempuan dapat menjadi $d z a w i ̂$ al-furûdh dan $d z a w i ̂ a l$-qarâbah. Selanjutnya, orang tua, janda, dan duda. Keutamaan berikutnya adalah saudara laki-laki dan perempuan, ibu dan ayah sebagai $d z a w \hat{\imath}$ al-qarâbah. Lebih luas lihat Hazairin, Hukum Kewarisan Bilateral Menurut Qur'an dan Hadith, h. 26-44. Lihat juga, Al Yasa Abu Bakar, Abli Waris Sepertalian Darah: Kajian Perbandingan terhadap Penalaran Hazairin dan Penalaran Fikih Mazhab, (Jakarta: INIS,1998), h. $37-$ 80. Khusus Syiah lihat Muhammad Mustafa Khan, Islamic Law of Inheritance: A New Approach, (New Delhi: Kitab Bhavan, 2005), Cet. III, h. 142-171.

${ }^{17}$ R. Subekti, Hukum Adat Indonesia dalam Yurispridensi Mahkamah Agung, (Bandung: Alumni, 1991), h. 15-16.

${ }^{18}$ R. Subekti dan J. Tamara, Kumpulan Putusan Mahkamah Agung Mengenai Hukum Adat, (Djakarta: Gunung Agung, 1965) h. 85-88. R. Subekti, Hukum Adat Indonesia dalam Yurispridensi Mahkamah Agung, h. $15-16$

${ }^{19}$ R. Subekti, Hukum Adat Indonesia dalam Yurispridensi Mahkamah Agung, h. 15-16. 
John Bowen di dalam bukunya Islam, Law and Equality in Indonesia menyatakan bahwa lewat putusannya, Mahkamah Agung telah mempromosikan sistem kewarisan bilateral ke seluruh pelosok Indonesia dan mengklaim bahwa kesamaan hak antara laki-laki dan perempuan merupakan hukum yang hidup di Indonesia. Lebih jelas Bowen menuliskannya sebagai berikut:

The Court used this concept of "living law" to promote the bilateral inheritance of property. In the 1950s, it made the modest stipulation that in any given society, men and women had equal rights to inherit unless otherwise specified by the specific social structure concerned. But in 1961 the Court declared that bilateral inheritance was now "the living law throughout Indonesia" and that superseded local adat in all cases. ${ }^{20}$

Setelah lahirnya keputusan Mahkamah Agung tersebut, yang menurut Subekti dipandang sebagai tonggak yang bersejarah dalam proses pencapaian persamaan hak antara kaum perempuan dan laki-laki, ${ }^{21}$ di kalangan masyarakat Karo terjadi polemik yang relatif tajam antara yang menolak dengan tegas putusan Mahkamah Agung dengan pihak yang menerima. Begitu "hangatnya" polemik yang terjadi di tengahtengah masyarakat, Bupati Karo yang saat itu dijabat oleh Matang Sitepu mengadakan seminar tentang Hukum Waris Adat Karo. Namun seminar tersebut tidak menghasilkan keputusan yang signifikan. ${ }^{22}$

Respon masyarakat Karo pada waktu itu tetap saja terbelah kepada tiga kelompok, yaitu: pertama, kelompok masyarakat yang setuju dengan persamaan kedudukan perempuan dan laki-laki dalam sistem hukum waris. Tokoh yang berada pada kelompok ini adalah P. Tamboen. Menurutnya, Keputusan Mahkamah Agung tanggal 1 Nopember 1961 adalah keputusan yang sangat tepat dan terpuji. P. Tamboen juga menyatakan keheranannya mengapa di Tanah Karo perempuan belum dianggap sama dengan lakilaki, sehingga perempuan harus tetap dibenamkan dalam lumpur kehidupannya. Seharusnya, masih menurut Tamboen, masyarakat Karo melihat ke depan dan bukan seperti yang lazim dilakukan banyak orang melihat ke belakang. ${ }^{23}$

Kedua, kelompok masyarakat yang setuju adanya

${ }^{20} \mathrm{John}$ Bowen, Islam, Law and Equality in Indonesia: An Anthropolgy of Public Reasoning, h. 53.

${ }^{21}$ R. Subekti dan J. Tamara, Kumpulan Putusan Mabkamah Agung Mengenai Hukum Adat, h.93.

${ }_{22}$ Ulasan singkat materi seminar tersebut dapat dibaca pada karya Djaja S. Meliala dan Aswin Peranginangin, Hukum Perdata Adat Karo dalam Rangka Pembentukan Hukum Nasional, (Bandung: Tarsito, 1979).

${ }^{23}$ Djaja S. Meliala dan Aswin Peranginangin, Hukum Perdata Adat Karo dalam Rangka Pembentukan Hukum Nasional, h.76. persamaan hak antara laki-laki dan perempuan, namun dengan catatan-catatan tertentu. Misalnya, persamaan kedudukan antara laki-laki dan perempuan tidak berlaku dalam pewarisan tanah adat. Salah seorang tokoh yang berada pada kelompok ini adalah $\mathrm{Dj}$. Ginting (istri almarhum Let. Jen. Djamin Ginting) yang mengatakan setuju dengan Keputusan Mahkamah Agung bahwa anak perempuan berhak mendapatkan harta waris sebagaimana anak laki, baik untuk harta bergerak ataupun tidak, kecuali satu hal yakni tanah adat. Adapun yang dimaksud dengan tanah adat adalah tanah pemulihen. ${ }^{24}$

Ketiga, kelompok yang sama sekali tidak setuju dengan persamaan kedudukan antara laki-laki dan perempuan dalam hal waris. Bagi mereka, dalam sistem hukum adat keduanya memang berbeda dan hal ini telah berlangsung dalam masa yang cukup panjang. ${ }^{25}$ Salah seorang tokoh yang tidak setuju dengan Keputusan Mahkamah Agung adalah Masri Singarimbun. Menurutnya, apabila sistem hukum waris masyarakat Karo diubah seperti Keputusan Mahkamah Agung, dikhawatirkan akan menimbulkan disintegrasi sosial yang hebat di tengah masyarakat Karo. ${ }^{26}$

Perdebatan yang terjadi di tengah-tengah masyarakat Karo tentang hak waris bagi anak perempuan menunjukkan bahwa persoalan ini sangat serius dan menyita perhatian banyak pihak. Putusan Mahkamah Agung tidak saja dianggap telah "mengganggu" kewibawaan hukum adat Karo yang telah diterima secara turun-temurun dalam rentang waktu yang cukup panjang, tetapi juga dikhawatirkan akan menimbulkan disintegrasi sosial di tengah-tengah masyarakat.

Lepas dari perdebatan tersebut, keputusan Mahkamah Agung mengukuhkan realitas pluralisme hukum di Tanah Karo. Masyarakat Karo disentakkan bahwa disamping norma adat, terdapat "hukum negara" yang putusan-putusannya tidak saja berbeda, tetapi juga bertentangan dengan apa yang mereka yakini selama ini. Masyarakat Karo, khususnya yang Muslim, pasca putusan Mahkamah Agung telah menjadi obyek lebih dari satu sistem hukum, yaitu adat, negara, dan agama. Pada saat itulah terjadi apa yang disebut dengan kompetisi norma, perjumpaan atau konflik di antara pelbagai sistem hukum.

Lepas dari itu, masyarakat Karo sudah menyatu dan merasa sangat nyaman dengan hukum adatnya.

\footnotetext{
${ }^{24}$ Djaja S. Meliala dan Aswin Peranginangin, Hukum Perdata Adat Karo dalam Rangka Pembentukan Hukum Nasional, h. 58.

${ }^{25}$ Djaja S. Meliala dan Aswin Peranginangin, Hukum Perdata Adat Karo dalam Rangka Pembentukan Hukum Nasional, h. 57.

${ }^{26}$ Djaja S. Meliala dan Aswin Peranginangin, Hukum Perdata Adat Karo dalam Rangka Pembentukan Hukum Nasional, h. 70.
} 
Aturan-aturan di dalam adat telah memenuhi apa yang sesungguhnya mereka butuhkan dalam hidup. Tentu bukan dalam makna material, tetapi lebih dari itu kebutuhan yang bersifat psikologis-magis-religius. Pendek kata, pola kekerabatan sangkep sitelu, merupakan pola kekerabatan yang menjamin setiap orang Karo memiliki nilai dalam konteks relasinya dengan orang lain. Pada sisi lain, kepatuhan mereka terhadap hukum adat merupakan bagian dari identitas mereka sebagai orang Karo.

Soerjono Soekanto menyebutkan beberapa teori dasar-dasar kepatuhan masyarakat terhadap hukum, yaitu: (1) Indoctrination. Masyarakat patuh pada hukum karena diberi indoktrinasi untuk berbuat demikian. Sejak kecil manusia telah dididik agar mematuhi kaidah-kaidah yang berlaku di dalam masyarakat. Bagaimanapun juga, kaidah-kaidah telah ada sejak seseorang dilahirkan dan semua manusia meneriman secara tidak sadar. Melalui proses sosialisasi, manusia dididik untuk mengenal, mengetahui, dan mematuhi kaidah-kaidah tersebut. (2) Habituation. Sejak kecil manusia mengalami proses sosialisasi, sehingga lama kelamaan menjadi suatu kebiasaan untuk mematuhi kaidah-kaidah tersebut. (3) Utility. Hukum dipatuhi karena dalam kesadaran batin masyarakat ada banyak manfaat yang bisa dipetik. Pendek kata, masyarakat patuh pada hukum karena nilai guna hukum itu sendiri. (4) Group Identification. Seseorang patuh pada hukum karena salah satu sarana untuk mengadakan identifikasi dengan kelompok. Implikasinya tidak jarang ada orang yang mematuhi kaidah lain hanya untuk mengadakan identifikasi dengan kelompok lain tersebut. ${ }^{27}$

Apabilaadatmemilikikedudukanyangsangatpenting bagi masyarakat Karo, maka dimana sesungguhnya posisi agama. Beranjak dari informasi yang diberikan para informan, penulis menangkap kesan bahwa bagi masyarakat Karo, agama dan adat memiliki wilayah atau teritorialnya masing-masing. Agama, khususnya Islam, hanya dipatuhi pada hal-hal yang bersifat ibadah seperti taharah, shalat, puasa, zakat, dan haji. Adapun persoalan perkawinan dan warisan, aturan-aturan yang dipakai adalah ketentuan-ketentuan yang telah digariskan adat. Dalam adat Karo, masalah perkawinan, kewarisan, dan juga kematian termasuk hal-hal yang ketentuannya sangat rinci diatur di dalam hukum adat. ${ }^{28}$

\footnotetext{
27 Soerjono Soekanto dan Soleman b. Taneko, Hukum Adat Indonesia, h. 323-32.

${ }^{28}$ P. Tamboen menguraikan bahwa yang termasuk ke dalam Adat Karo adalah hal-hal yang berhubungan dengan marga, pantangen, berdirinya urung, tabiat bangsa, keadaan kesehatan, kampung-kampung, peralatan dan upacara, anak lahir, perkawinan, menguburkan orang mati, mentabalkan raja, agama, kesenian, dan sebagainya. Hal menarik
}

Dengan demikian, penjelasan di atas sampai pada sebuah pernyataan yang konklusif bahwa masyarakat Karo Muslim, dalam praktik hukum warisnya ternyata masih menggunakan hukum adat. Akan tetapi kendati mereka sama-sama menyebut hukum adat, tetapi polanya antara satu dengan yang lain berbeda-beda. Lalu pertanyaannya adalah apakah hukum adat yang mereka laksanakan benar-benar murni dan utuh sebagaimana yang telah digariskan nenek moyang mereka sejak dahulu kala?

\section{Pola-Pola Kewarisan Anak Perempuan}

Berangkat dari informasi yang diberikan para informan, penulis menemukan setidaknya terdapat tiga pola yang berkembang pada masyarakat Karo Muslim dalam kaitannya dengan pembagian harta waris untuk anak perempuan. Tiga pola tersebut yaitu: pertama, anak perempuan tidak mendapat harta waris. Penelitian yang dilakukan menunjukkan bahwa di antara informan ternyata masih ada yang melaksanakan hukum adat secara utuh. Hal ini sebagaimana yang ditunjukkan oleh beberapa informan bahwa selaku anak perempuan, mereka tidak mendapatkan harta waris sedikit pun dari saudaranya yang laki-laki. ${ }^{29}$ Ada pula informan yang mengatakan bahwa disebabkan harta waris yang sedikit, saudara perempuannya rela untuk tidak mendapatkan apapun dari harta waris tersebut. Tidak kalah menariknya, ketika saudara perempuannya tidak menuntut apapun dari harta waris tersebut, dipahami sebagai bentuk kesadaran dan kepatuhan saudara perempuan tersebut terhadap hukum adat. Tegasnya, perempuan yang patuh pada hukum adat, dipandang sebagai perempuan Karo yang baik dan beradat.

Adat Karo menempatkan laki-laki dan perempuan dalam posisi yang tidak seimbang. Anak laki-laki sebagai pembawa marga mendapatkan kehormatan-kehormatan di dalam pelbagai peristiwa adat, termasuk di dalamnya pada proses pembagian harta waris. Kedudukannya yang tinggi juga menempatkannya sebagai orang yang

dari Tamboen, hukum pusaka (waris) dimasukkan pembahasannya dalam sub hukum sipil. Termasuk dalam pembahasan hukum sipil adalah hukum tanah, jual beli dan sewa, hukum nikah, hukum lakoman (kawin waris), hukum kaum keluarga, hukum gadai-menggadai, dan hal yang berhubungan dengan pengadilan. P. Tamboen, Adat Istiadat Karo, (Djakarta: Balai Pustaka, 1952), h. 1-205. Bandingkan dengan Darwins Prints, Adat Karo, (Medan: Bina Media Perintis, 2004), h. 71362. Tema-tema dalam buku Darwins Prints adalah perkawinan pada masyarakat Karo, nurunken kalak mate, adat untuk anak-anak, remaja, dan orang tua, rumah adat Karo, adat tanah dan pertanian, aneka kebudayaan Karo, Sangkep ngeluhi, Maba Belo Selambar, Nganting Manuk, Ertembe-tembe Pedalan Emas, Ngerungguken kalak idilo dibata dan runggu mulih kuburen nari.

${ }^{29}$ Djaja S. Meliala dan Aswin Peranginangin, Hukum Perdata Adat Karo dalam Rangka Pembentukan Hukum Nasional, h. 41. 
harus didahulukan, bahkan diutamakan. Menariknya, perempuan Karo sebenarnya sangat menyadari posisi yang tidak seimbang tersebut. Oleh sebab itu, ekspresi inferioritas ditunjukkan dengan sikap mengalah, tidak menuntut harta waris, dan merelakan harta orang tuanya jatuh kepada saudaranya yang laki-laki.

Disamping itu, perempuan Karo juga menyadari aturan-aturan adat yang menempatkan mereka sebagai makhluk "kelas dua" dan hal itu dirasakan sebagai sesuatu yang tidak mencerminkan keadilan. Pada satu sisi, anak perempuan biasanya menjadi tempat orang tua mengadukan pelbagai hal. Anak perempuan menjadi teman berbagi cerita. Bahkan ketika orang tua sakit, anak perempuanlah yang mengurusnya. Ini dipandang sebagai kewajiban. Bahkan tidak jarang, anak perempuan bukan hanya sekedar mengurus tetapi juga menanggung biaya pengobatannya. Dalam kenyataannya, orang tua pun merasa lebih nyaman tinggal dengan anak perempuannya ketimbang dengan anak laki-lakinya (bersama menantu perempuannya). Namun pada sisi lain, pada saat pembagian harta waris, mereka sama sekali tidak mendapatkan harta waris. Inilah sesungguhnya yang membuat perempuan Karo "protes", walaupun ekspresinya hanya tampak dalam kata-kata.

Kedua, anak perempuan mendapatkan sedikit harta waris. Bentuk lain dari pelaksanaan hukum waris di tanah Karo adalah mulai munculnya kesadaran masyarakat Karo Muslim (saudara laki-laki) untuk memberi harta waris kepada anak perempuan atau saudara perempuannya. Terlepas apapun namanya, apakah anak perempuan sebagai ahli waris dan karenanya mendapatkan bagian waris atau sekedar pemberian dari saudara laki-laki sebagai tanda kasih sayang dan penghargaan, perempuan Karo sudah mendapatkan harta waris kendati dalam jumlah yang sangat kecil.

Kesadaran di masyarakat Karo untuk memberi harta waris kepada anak perempuan disebabkan kemurahan hati saudara laki-lakinya. Oleh sebab itu, harta yang diterima anak perempuan disebut sebagai pemerean, tanda kasih sayang, atau penghargaan. Disamping itu, anak perempuan memperoleh harta waris karena mereka dipandang berhak untuk menerimanya. Biasanya dalam kasus ini berlaku wasiat atau hibah dari orang tua.

Ketiga, anak perempuan dipandang sejajar dengan anak laki-laki. Hal ini masih dalam konteks perubahan pada hukum adat Karo. Pada bentuk yang pertama dan kedua jelas terlihat bagaimana pilihan-pilihan hukum yang dilakukan masyarakat Karo Muslim dalam rangka menyelesaikan pembagian harta warisnya. Masih ada yang bertahan pada hukum adat dan jumlahnya sangat kecil. Diperkirakan bahwa pada masa-masa mendatang, semakin banyak masyarakat Karo Muslim yang akan melakukan "penyimpangan" dari garis hukum adatnya. Setidak-tidaknya mereka akan melakukan modifikasi terhadap hukum adat warisnya.

Berbeda dengan bentuk yang pertama dan kedua, pada bentuk yang ketiga ini harta waris akan dibagi kepada ahli waris dalam jumlah yang sama. Istilah yang dipakai sama rata. Perbedaan antara laki-laki dan perempuan tidak lagi bermakna perbedaan jumlah porsi bagian. Tentu bentuk yang ketiga ini melampaui apa yang dituntut hukum adat dan juga hukum Islam itu sendiri.

Cara ini ditempuh para orang tua, disamping untuk menciptakan keadilan di antara anak-anaknya, juga bertujuan untuk menghindarkan konflik di antara sesama ahli waris. Walaupun sampai hari ini kesadaran wanita Karo untuk menuntut haknya belum tampak dengan jelas, namun tidak tertutup kemungkinan pada masa mendatang, kesadaran hukum bagi wanita Karo akan semakin menguat.

Tidak kalah menariknya, beberapa informan menyebut bahwa apa yang mereka lakukan dengan memberi harta kepada anak perempuan, bagaimanapun caranya, adalah bentuk dari kombinasi antara hukum adat dan hukum agama. Bagi mereka, lebih penting untuk mempertahankan harmonisasi keluarga, ketimbang membiarkannya retak dan hancur hanya karena pembagian harta waris yang tidak adil.

\section{Pola Kewarisan Janda}

\section{Janda yang Belum Bercerai dari Suaminya}

Bagi orang Karo, kematian salah satu pasangan tidak dimaknai sebagai perceraian. Tentu saja hal ini berbeda dengan apa yang berlaku di dalam hukum Islam dan hukum perdata. Perceraian yang disebabkan karena kematian dan menyebabkan istri yang ditinggalkan disebut dengan janda almarhum tetap menjadi bagian dari keluarga laki-laki. Hal ini adalah konsekuensi logis dari tardisi unjuken-tukur dalam adat istiadat Karo. ${ }^{30}$

${ }^{30}$ Salah satu bentuk kawin eksogami dalam masyarakat hukum adat kebapaan adalah suatu sistem perkawinan yang terkenal dengan nama kawin jujur. Menurut sistem perkawinan ini, pihak calon suami memberi sesuatu yang bersifat magis kepada pihak calon istri, yang biasanya adalah seorang gadis, dan segera sesudah pihak calon istri, yang biasanya sesuatu yang bersifat magis itu, maka klan dari calon istri melepaskan ikatan kekeluargaannya dan secara otomatis calon istri masuk ke dalam lingkungan klan dari bakal suaminya. Dengan demikian, istri menjadi anggota (baru) dari klan suaminya dengan diberi hak dan kewajiban penuh dalam lingkungan keluarga suaminya itu. Bushar Muhammad, Asas-Asas Hukum Adat: Suatu Pengantar, (Jakarta: Pradnya Paramita, 2006), h. 24-25. Selanjutnya, hampir semua pada 
Wafatnya suami tidak menyebabkan berkurangnya hak-hak janda terhadap harta suaminya. Janda memiliki hak penuh untuk mengelola harta, mengembangkannya, dan menikmatinya.Lebih penting dari itu, janda memiliki kewenangan untuk mendayagunakan harta suaminya demi kepentingan anak-anaknya, apakah dalam rangka pendidikan, memperoleh pekerjaan, atau pun untuk kehidupan keluarga (perkawinan). Beberapa informan memberi catatan, persetujuan kalimbubu dan anak beru penting untuk dimintakan apa bila janda tersebut bermaksud ingin menjual sebagian harta.

Informasi yang penulis temukan, bagi sebagian orang, hak janda untuk mengelola harta suaminya secara penuh selama belum terjadi perceraian seperti yang berlaku di dalam hukum adat, dipersamakan dengan hak waris. Tegasnya, janda mewarisi harta suaminya dengan cara mengelola dan memeliharanya.

Kemungkinan lain untuk mempertahankan kedudukan janda di lingkungan keluarga suaminya adalah melalui perkawinan lakoman. Jenis perkawinan ini juga disebut dengan perkawinan waris. Artinya, jika suami meninggal, maka jandanya dapat dinikahi oleh pihak-pihak yang memiliki tutur yang sama dengan suaminya, semisal anak suaminya dari ibu yang lain atau dengan saudara laki-lakinya yang lain. ${ }^{31}$ Dengan berlangsungnya pernikahan, maka kedudukan janda kembali penuh sebagai bagian dari anggota keluarga suaminya. Biasanya, perkawinan lakoman ini terjadi jika janda yang ditinggalkan masih muda. Salah satu alasan perkawinan lakoman ini adalah agar sang janda tidak keluar dari klan suaminya.

masyarakat yang menganut perkawinan jujur memiliki pola yang sama. Pada suku bangsa Rejang, sistem perkawinannya bukan saja eksogami, tetapi juga menjamin garis keturunan yang patrilineal. Dengan kawin jujur, si perempuan beleket (jujur) dilepaskan dari golongan sanak saudaranya dan dimasukkan bersama anak-anaknya ke golongan sanak saudara dari suami, disamping kenyataan si perempuan beleket wajib pula bertempat tinggal di tempat suaminya, setidak-tidaknya di tempat keluarga suami. Abdullah Siddik, Hukum Adat Rejang, (Jakarta: Balai Pustakan, 1977), h. 225-226.

${ }^{31}$ Ada beberapa jenis perkawinan lakoman yang berlaku di dalam adat Karo, yaitu: (1) Seorang janda pertama kali diminta adat supaya dilakomangani oleh ahli waris yang haknya dari tuturnya sama dengan suaminya dulu, seperti anak dari lain ibu atau saudara-saudara kandung suaminya yang meninggal, dinamai "lakoman tiaken" dan kalau itu tidak ada atau sebab tidak mau, maka boleh, (2) Saudara-saudaranya berlainan ibu, tetapi satu bapa atau satu turunan dari marga dan hal itu dinamai "lakoman ngalihken senina". (3) Kedua diminta adat kalau tidak ada anak kandung suami dari lain ibu atau ada tetapi masih di bawah umur, maka boleh oleh anak saudara suaminya, dinamai kejadian ini dengan "lakoman ku nandena" (nande di sini bukan emak kandung). (4) Boleh jadi tidak sesuai menurut 1-3, bisa juga cucu laki-laki dari suami janda yang menurun dari lain ibu lakoman kepada janda itu. Ini dinamai, "lakoman mindo latjina ku nina”. P. Tamboen, Adat Istiadat Karo, h. 156.

\section{Janda yang Telab Dinyatakan Bercerai}

Cerai hidup bagi orang Karo sebenarnya adalah sebuah peristiwa yang sangat tidak disukai, walaupun hukum adat tidak menutup pintu sama sekali bagi pasangan suami-istri untuk bercerai sepanjang ada alasan yang cukup kuat. ${ }^{32}$ Atas dasar itulah, perkawinan menurut adat Karo termasuk jenis upacara adat yang cukup panjang dan melelahkan. Namun harus dicatat, pelaksanaan adat dan upacara perkawinan yang dianggap "panjang" dan "rumit" itu akan memberi berkah, dalam pengertian tidak mudah bagi suamiistri untuk bercerai. Kalau karena hal-hal kecil mereka bercerai, itu artinya mereka tidak pernah menghargai pengorbanan karib-kerabatnya dan handai tolan yang sudah bersusah-payah mengurusi perkawinan mereka. ${ }^{33}$

Disamping itu, konsep perkawinan unjuken (tukur) meniscayakan perkawinan itu bersifat abadi. Dalam perspektif adat Karo, ketika perkawinan sudah terjadi, maka "hubungan" anak perempuan, yang kemudian menjadi istri dari suaminya, dengan keluarganya menjadi "terputus". Sampai-sampai harta warisan saja mereka tidak diberi karena dipandang telah menjadi tanggung jawab suaminya. Anak perempuan yang telah "dibeli" tersebut pindah ke clan suaminya dan menjadi bagian dari keluarga suaminya. Jika suaminya mati, tidak ada satu pun yang dapat mengusir janda tersebut kecuali atas permintaannya sendiri.

Berbeda halnya dengan cerai hidup. Jika terjadi perceraian antara suami dan istri karena satu dan lain hal, maka hubungan menjadi terputus sama sekali. Dalam hal ini, janda tidak mendapatkan apa pun dari suaminya kecuali harta bawaannya. Untuk harta yang disebut terakhir ini, tetap menjadi milik janda tersebut dan ia menguasai sepenuhnya. Pertanyaannya adalah apakah hukum adat Karo mengenal harta bersama?

Menurut Djaja Meliala, harta sarekat sebenarnya tidak dikenal di dalam masyarakat Karo karena semua harta yang diperoleh selama perkawinan (kecuali harta rumah tangga) adalah milik suami. Harta rumah tangga (seperti perabot-perabot rumah tangga) jika terjadi perceraian akan dibagi dua sama rata, antara suami dan istri. $^{34}$

${ }^{32}$ Alasan yang sering digunakan sebagai alasan cerai dalam hukum adat Karo adalah tidak mempunyai keturunan, terutama keturunan laki-laki. Alasan lain adalah terjadi perzinaan, salah satu pihak ada mengandung penyakit yang tidak dapat diobati (lepra), dan sebagainya. Darwins Prints, Adat Karo, h. 128 dan P. Tamboen, Adat Istiadat Karo, h. 152.

${ }^{33}$ Tridah Bangun, Penulisan dan Pencatatan Adat Istiadat Karo, (Jakarta: Yayasan Merga Silima, 1990), h. 127.

${ }^{34}$ Djaja S. Meliala dan Aswin Peranginangin, Hukum Perdata Adat Karo dalam Rangka Pembentukan Hukum Nasional, h. 41. 
Dengan demikian, dalam konteks kewarisan janda, penulis menemukan dua pola yang umumnya berlaku di kalangan masyarakat Karo Muslim, yaitu pertama, diberikannya hak kepada janda untuk menggunakan (men-tasharruf-kan) harta mendiang suaminya dipahami bahwa janda sebenarnya telah mewarisi harta dari suaminya. Bahkan janda tersebut memiliki hak dan kewenangan untuk membagi-bagi harta warisan tersebut kepada anak-anaknya. Terkadang kesempatan ini dimanfaatkan para janda untuk memberikan harta kepada anak perempuannya walaupun dalam jumlah yang sangat terbatas.

Sampai di sini menjadi menarik untuk dipahami bahwa dalam persepsi masyarakat Karo, hak untuk mengelola dan memanfaatkan harta waris suaminya dimaknai sebagai hak mewarisi. Bagi mereka, kata "mewarisi" tidak semata-mata bermakna memiliki. Namun lebih penting dari itu, mereka memaknai mewarisi dengan menguasai.

Kedua, janda, walaupun diberi hak untuk memanfaatkan harta waris, namun hak tersebut sangat terbatas. Ia diberi hak untuk mengelola dan menggunakan harta sebatas untuk keperluan hidupnya dan anak-anaknya. Bahkan seandainya janda tersebut telah membagi harta, termasuk untuk anak perempuannya, maka anak laki-laki tersebut dapat meminta kembali harta tersebut setelah ibunya meninggal dunia. Ini menunjukkan bahwa Ibu tidak memiliki hak untuk membagi harta waris tersebut, walaupun kepada anaknya sekalipun. Pendek kata, janda pada hakikatnya tidak memiliki keleluasaan untuk menggunakan harta suaminya.

Sebenarnya, janda tidak mendapatkan hak waris merupakan bentuk asal dari hukum waris Karo. ${ }^{35}$ Djaja Meliala dan Aswin Peranginangin menuliskan bahwa selama janda melaksanakan darmanya sebagai seorang janda, kepadanya hanya diberi hak menikmati hasil dari harta kekayaan suaminya dan ia bukanlah ahli waris. ${ }^{36}$ Menurut Ter Haar, kaitannya dengan janda, titik pangkalnya janda tidak memperoleh harta waris adalah karena perempuan (janda) itu dipandang sebagai orang asing dan tidak berhak atas warisan. Akan tetapi sebagai isteri, ia ikut memiliki harta benda yang

${ }^{35}$ Di dalam hukum adat khusus pada masyarakat yang menganut asas patrilineal, janda tidak mendapatkan bagian dari harta peninggalan suaminya sebagai ahli waris tetapi berhak menarik penghasilan dari harta tersebut, jika perlu seumur hidup. Untuk nafkah janda tersebut disediakan barang gono-gini jika barang-barang ini mencukupi dari harta peninggalan suaminya. Soekanto, Meninjau Hukum Adat Indonesia: Suatu Pengantar untuk Mempelajari Hukum Adat, (Jakarta: Rajagarfindio1996), h. 116-117.

${ }^{36}$ Djaja S. Meliala dan Aswin Peranginangin, Hukum Perdata Adat Karo dalam Rangka Pembentukan Hukum Nasional, h. 56. diperoleh selama perkawinan dalam batas-batas yang telah ditetapkan. Janda tersebut, masih menurut Ter Haar, juga berhak atas nafkah dari harta peninggalan suaminya seumur hidupnya kecuali ada ketentuan yang menentukan lain. ${ }^{37}$

\section{Dinamisasi Hukum Waris Adat Karo}

Studi ini memperlihatkan bahwa kendatipun masyarakat Karo Muslim mengaku menggunakan hukum adat untuk menyelesaikan pembagian harta waris, namun pada praktiknya mereka tidak lagi menerapkan hukum adat tersebut secara murni. Hal ini menunjukkan bahwa pandangan-pandangan yang menyatakan hukum adat itu statis ternyata tidak dapat dibenarkan.

Sampai di sini, menarik mencermati apa yang dituliskan oleh Tjok Istri Putra Astiti yang meneliti tentang hak-hak wanita Bali dalam hukum adat waris. Ia menyatakan:

Jika kita bertolak dari pengertian hukum adat sebagai hukum rakyat yang tumbuh dan berkembang di masyarakat, hukum adat bukanlah hukum yang bersifat statis, melainkan dinamis. Sifat dinamis dari hukum adat itu digambarkan antara lain oleh Koesnoe dengan istilah "luwes", Kusumadi Pujusewoyo (1961) dengan ungkapan "menebal dan menipis", Nasroen (1957) dengan istilah "patah tumbuh hilang berganti", dan menurut istilah Bali adalah menyesuaikan diri dengan desa, kala, patra (berubah menurut tempat, waktu, dan keadaan)..$^{38}$

Hukum adat itu dinamis dan tentu saja akan berubah. Persoalannya bukan sekedar berubah atau tidaknya, melainkan kemana arah perubahan tersebut. Dalam konteks masyarakat Karo, pluralisme hukum merupakan sebuah realitas yang tidak terbantahkan. Hukum adat pada satu sisi akan berhadapan, berkompetisi, saling mempengaruhi, atau malah bergerak dan mendekat membentuk pola-pola baru.

Dalam kasus kewarisan anak perempuan misalnya, masyarakat Karo Muslim mulai menyadari bahwa anak perempuan juga memiliki hak untuk mendapatkan harta waris dari orang tuanya. Tidak berhenti hanya pada kesadaran, mereka juga telah merumuskan langkah-langkah atau strategi-strategi baru agar harta tersebut sampai kepada anak perempuannya tanpa harus berbenturan secara langsung dengan hukum adat.

Hukum adat masih mendominasi kehidupan

\footnotetext{
${ }^{37}$ Ter Haar, Asas-Asas dan Susunan Hukum Adat, (Djakarta: Pradnya Paramita, 1991), h. 217.

${ }^{38}$ Tjok Istri Putra Astiti, "Hak-Hak Wanita Bali dalam Hukum Adat Waris", dalam E.K.M. Masinambaow (ed.), Hukum dan Kemajemukan Budaya: Sumbangan Karangan untuk Menyambut Ulang Tahun ke-70 Prof. Dr.O. Ihromi, (Jakarta: Obor, 2000), h. 317.
} 
masyarakat Karo Muslim walaupun Islam sebagai agama yang mereka peluk memiliki seperangkat aturan dan norma yang berkaitan dengan hukum-hukum keluarga. Ketika penulis bertanya, mengapa mereka tidak menggunakan hukum Islam, mereka mengatakan bahwa "Adat yang lebih dahulu ada dari agama. Jadi mana bisa diubah".

Seiring dengan perjalanan waktu, hukum adat yang selama ini dilaksanakan masyarakat Karo (Muslim), perlahan namun pasti, hukum warisnya sedang mengalami pergeseran bahkan perubahan. Kendatipun anak perempuan mendapatkan harta waris dari saudara laki-lakinya, bukan dari orang tuanya langsung, keadaan itu jauh lebih baik dari yang terjadi pada eraera sebelumnya.

Studi ini menunjukkan bahwa faktor emosional saudara laki-laki menjadi sangat menentukan bagi perolehan harta waris anak perempuan. Informasi yang penulis terima dari beberapa informan tidak memperlihatkan indikasi yang kuat, bahwa perubahan itu terjadi karena anak laki-laki sudah menyadari apa yang disebut dengan kesetaraan jender. Pemberian itu sama sekali tidak didasarkan pada paham kesamaan derajat. Anak laki-laki tetap merasa superior dibanding anak perempuan. Studi ini telah memperlihatkan bahwa ketika penulis bertanya bagaimana kedudukan anak laki-laki dalam alam pikiran orang Karo, jawaban yang dapat penulis tangkap adalah mereka mengakui bahwa kedudukan anak laki-laki lebih tinggi dibanding anak perempuan. Laki-laki Karo diposisikan superior terhadap perempuan di pelbagai sektor kehidupan, domestik maupun publik. Di sektor domestik sekalipun, perempuan cenderung diposisikan sebagai subordinat laki-laki, misalnya dalam kontrol hak milik rumah tangga, distribusi pekerjaan rumah tangga, dan juga dalam hal pengambilan keputusan. Sebagai kelanjutannya adalah kontrol sumber daya rumah tangga ada di tangan laki-laki dan tidaklah aneh jika warisan pun lebih banyak mengalir kepada anak lakilaki. ${ }^{39}$

Kendati demikian, menurut Rahngena Purba, saat ini sebenarnya telah berlangsung perlawanan "diamdiam" yang dilakukan oleh perempuan Karo. Dalam tulisannya tentang peran istri dalam ekonomi rumah tangga, dengan mengambil sampel wanita-wanita yang ada di daerah rural dan heterogen, terbukti, seorang

${ }^{39}$ Muhadjir Darwin dan Tukiran, Menggugat Budaya Patriarki, (Yogyakarta: Pusat Penulisan Kependudukan Universitas Gajah Mada dan Ford Foundation, 2006), h. 3 dan 24 -25. Bandingkan dengan Irwan Abdullah, Seks, Gender \& Reproduksi Kekuasaan, (Yogyakarta: Tarawang, 2001), h. 26-27. wanita yang aktif dalam ekonomi rumah tangga dan juga rajin, ternyata mereka memiliki posisi tawar kuat sehingga pengambil keputusan dalam ekonomi juga kuat untuk tidak mengatakan sangat menentukan. Sebagai contoh di daerah Ujung Sampun, ditemukan rumah-rumah penduduk yang ditempeli nama sang pemiliknya. Biasanya yang terjadi selama ini, nama yang ditempel hanya nama suami. Tetapi di Ujung Sampun keadaannya telah berubah. Nama suami dan istri keduanya ditonjolkan. Misalnya tertulis di papan nama sepasanga nama suami-istri, A Barus, $\mathrm{B} \mathrm{Br}$ Ginting. Bukankah ini bermakna pernyataan seorang wanita bahwa rumah ini bukan hanya milik suaminya tetapi juga miliknya (istri). Bukankah ini merupakan sebuah pemberontakan. ${ }^{40}$

Penulis cenderung menyebutnya dengan pemberontakan bisu. Pendek kata, semakin aktif perempuan Karo dalam kegiatan ekonomi, maka semakin kuat posisi tawarnya dalam pelbagai bidang, misalnya dalam hal sekolah anak dan pertanian. Sebagai kelanjutannya, jika posisi ibu semakin kuat dalam rumah tangga seiring dengan tingginya kontribusinya dalam ekonomi keluarga, maka wewenangnya untuk mendistribusikan harta kepada anak perempuannya semakin kuat pula. Seiring dengan kuatnya posisi ibu, maka peluang anak perempuan untuk memperoleh harta waris semakin terbuka. Setidaknya, sang ibu semakin bebas untuk melakukan strategi distribusi harta kepada anak perempuan. Tentu saja dibanding dengan perempuan Batak Toba, perempuan Karo tampaknya tidak menunjukkan ekspresi pemberontakannya terhadap dominasi adat dengan cara-cara yang vulgar.

Penulis melihat, perubahan hukum adat waris Karo yang signifikan akan terjadi ketika setiap orang tua melakukan upaya-upaya yang serius dan sistematis untuk memberikan hak kepada anak perempuan dalam memperoleh harta waris. Sejatinya, para orang tua harus menggunakan otonomi dan kekuasaan yang mereka miliki untuk memberi akses terhadap harta waris buat anak-anak perempunnya.

Studi yang dilakukan Franz Von Benda Beckmann tentang Property in Social Continuity (Properti dan Kesinambungan Sosial) menunjukkan bahwa hukum kewarisan Islam dalam lingkungan adat Minangkabau telah mengalami perubahan-perubahan. Beckmann menunjukkan banyak orang tua laki-laki dalam kapasitasnya sebagai mamak, yang semestinya lebih bertanggung jawab kepada kemanakannya telah beralih untuk lebih memperhatikan anak-anaknya.

${ }^{40}$ Wawancara dengan Ibu Rahngena Purba pada tanggal 13 Juli 2010 di Jakarta. 
Mereka telah melakukan upaya-upaya sistematis untuk memberikan harta pencaharian kepada anakanaknya, baik melalui jalur hibah atau wasiat. Hal ini sebenarnya untuk menghindarkan konflik antara anak dan kemanakan di belakang hari nanti. Dalam bahasa Backmann, "Bukan menjadi rahasia umum lagi bahwa konflik klasik dalam hal pewarisan di Minangkabau adalah situasi dimana anak dan kemanakan orang yang meninggal mempersengketakan harato pencaharian almarhum bapak atau mamaknya". ${ }^{41}$

Berikut ini pernyataan Backmann tentang upaya sistematis yang dilakukan para orang tua untuk mengalihkan properti kepada anak-anak mereka:

Semasa hidupnya, mereka dapat giat menggunakan otonomi mereka untuk mendahului pengalihan diakronis atau mengganti ketentuan-ketentuan pewarisan tanpa wasiat dengan petunjuk-petunjuk yang mereka buat sendiri. Mereka dapat melakukan itu dalam batas-batas yang ditentukan hukum, dan tentu mereka juga mencoba berbuat sesuatu yang melanggar hukum. Ketentuan-ketentuan adat sudah digambarkan sebagai berikut: (1) Antisipasi terhadap pengalihan diakronis dengan melakukan hibah yang dapat dilakukan semasa pemegang properti masih hidup dan dengan menanamkan modal dalam pelbagai bentuk properti yang akan langsung menguntungkan orang-orang yang mereka sukai, seperti penanaman tanaman keras bagi anak-anak dan pengalihan gadai kepada istri dan anak. (2) Mengganti ketentuan pewarisan tanpa wasiat dapat dilakukan dengan cara hibah (yang dapat ditarik kembali selama pemegang properti masih hidup) atau melalui wasiat. (3) Pemilik juga dapat mengendalikan pentas untuk pewarisan yang akan datang dengan mengubah status hukum dari objek properti; kemungkinan yang sekarang diberikan untuk tanah yang dapat diubah menjadi "hak milik" di bawah Undang-Undang Pokok Agraria sehingga terhadap tanah demikian akan diterapkan hukum harato pencaharian. ${ }^{42}$

Gejala yang terjadi di Minangkabau saat ini, ketika pewaris lebih menginginkan harta warisnya jatuh kepada orang-orang yang dicintainya, disebut oleh Backmann sebagai gejala "individualisasi". Dalam kesimpulannya, ia mengatakan bahwa kebanyakan orang tua bersikap mendahulukan kepentingan satuan-satuan sosial yang kecil, seperti keluarga, suami-istri, anak, dan cucu. Sikap mereka terhadap keluarga lain semakin menunjukkan rasa acuh tidak acuh. Dalam menyimpulkan perubahan, hendak diberikan perhatian utama pada proses individualisasi dan kedekatannya kepada kelompokkelompok sosial yang kecil serta rontoknya kelompok sosial yang lebih besar seperti rumah gadang dan kaum, dari pada perhatian pada perubahan yang terjadi dari

${ }^{41}$ Franz Von Benda Beckmann, Properti dan Kesinambungan Sosial, diterjemahkan oleh Tim Perwakilan KITLV dan Indira Simbolon, (Jakarta: Grasindo, 2000), h. 340.

${ }^{42}$ Franz Von Benda Beckmann, Properti dan Kesinambungan Sosial, h. 353-354.

\section{"kemanakan" kepada anak. ${ }^{43}$}

Studi Backmann membuktikan bahwa tidak hanya perubahan di dalam konsepsi hukum adat yang sangat memungkinkan, dan ternyata telah terjadi, namun yang agaknya perlu mendapatkan perhatian yang lebih besar diberikan adalah perubahan tersebut lebih banyak disebabkan oleh "gerakan" masyarakat adat itu sendiri. Pergulatan batin, bahkan konflik batin, yang terjadi pada setiap individu di dalam masyarakat adat mendorong mereka untuk kembali mempertanyakan konsep-konsep hukum adat yang selama ini dianggap pasti benar. Pada saat yang sama, perubahan sosial juga ikut mempengaruhi sikap dan pandangan terhadap hukum adat. Pertumbuhan penduduk yang sangat cepat dan berimplikasi terhadap berkurangnya tanah, membuat masyarakat Minang, terutama laki-laki, untuk fokus pada harta pencaharian dan tidak lagi bergantung pada harta kaum. ${ }^{44}$

Sebab lain, menurut saya, yang paling penting adalah semakin banyak laki-laki tinggal bersama istrinya dan semakin berkurang fungsinya sebagai mamak, semakin banyak pula lelaki yang mencurahkan perhatian dan kegiatan ekonominya pada rumah dan properti istri dan anak-anaknya, mengerahkan tenaga dan harta pencahariannya bagi kepentingan orangorang yang hidup bersamanya. Pola tempat kediaman ekonomi yang baru semakin meningkatkan investasi harta pencaharian laki-laki bagi kepentingan keluarga batih-nya, biasanya investasi pada harta pusaka istri, menyebabkan meningkatnya individualisasi harta pusaka istri dan menyebabkan besarnya pengaruh dan otonomi keluarga batih dibandingkan kaum istri. ${ }^{45}$

Jika masyarakat Minangkabau yang terkenal sebagai masyarakat yang cukup kuat memegang adat pada satu sisi dan agama pada sisi lain, sehingga mampu mengharmonisasikan adat dan agama dalam satu ungkapan yang sarat makna yaitu "Adat basandi syara', syara'basandi kitabullah", hukum adatnya sedang mengalami perubahan-perubahan. Hal yang sama juga sedang terjadi di Tanah Karo.

Apakah terjadinya perubahan pada hukum adat waris Karo disebabkan oleh usaha-usaha sistematis para orang tua untuk memberikan harta (waris) kepada anak perempuannya? Berbeda dengan apa yang terjadi pada masyarakat Minangkabau, ketika konflik yang terjadi

\footnotetext{
${ }^{43}$ Franz Von Benda Beckmann, Properti dan Kesinambungan Sosial, h. 469 .

${ }^{44}$ Franz Von Benda Beckmann, Properti dan Kesinambungan Sosial, h.472.

${ }^{45}$ Franz Von Benda Beckmann, Properti dan Kesinambungan Sosial, h. 477.
} 
antara anak dan kemanakan dalam hal pembagian harta, pada masyarakat Karo, konflik sejenis itu tidak terjadi sama sekali. Seandainya ada konflik, hal itu terjadi antara anak laki-laki dan anak perempuan. Para orang tua Karo hanya bertugas agar di antara anak-anaknya terjadi perdamaian. Namun lebih penting dari sekedar perdamaian, mereka juga bertanggung jawab terhadap masa depan anak perempuannya. Sedapat mungkin mereka berusaha agar anak perempuannya tidak merasa disisihkan dan atau diperlakukan secara tidak adil.

Informasi yang penulis dapatkan menunjukkan ada kecenderungan orang tua, baik laki-laki, terlebih ibu (istri), untuk memberikan harta waris kepada anak perempuannya melalui dua cara, yaitu hibah dan wasiat. Yang dimaksud dengan hibah adalah harta diberikan sewaktu orang tua masih hidup. Proses ini semakin mudah dilakukan karena anak perempuan masih tinggal bersama orang tuanya. Pemberian harta dari orang tua juga dilakukan ketika anak perempuannya melangsungkan pernikahan. Adapun wasiat, biasanya diberikan kepada anak laki-laki agar mereka memperhatikan saudaranya yang perempuan.

Dibanding wasiat, hibah lebih memiliki kepastian bagi anak perempuan untuk memperoleh harta dari orang tuanya. Biasanya, harta yang diberikan adalah harta pencaharian. Tanah dan benda-benda yang tidak bergerak sama sekali sulit diperoleh anak perempuan karena kuatnya dominasi adat. Kendati demikian, peluang untuk mendapatkan harta tidak bergerak walaupun dalam jumlah yang terbatas tetap saja terbuka.

Salah satu bentuk perubahan itu adalah munculnya dorongan untuk membedakan harta adat seperti tanah dan rumah dengan harta pencaharian semakin kuat. Berkaitan dengan harta adat, tampaknya peluang anak perempuan untuk memperoleh bagian harta waris masih sulit, kecuali ada kebijakan-kebijakan khusus dari saudaranya yang laki-laki. Namun untuk harta pencaharian, tuntutan untuk "sama rata" semakin menemukan momentumnya seiring dengan perubahan zaman. Berkaitan dengan hal ini, menarik mencermati apa yang dituliskan oleh M.U. Sembiring sebagai berikut:

Dalam hukum waris, norma yang berlaku adalah bahwa anak perempuan tidak mempunyai hak untuk mewarisi. Apa yang mereka terima dari harta orangtuanya hanyalah "pemberian" saudara laki-lakinya, bukan hak anak perempuan. Dewasa ini dapat dikonstatir bahwa pada kalangan tertentu terutama di daerah perkotaan telah timbul gejala rasa tidak puas terhadap norma tersebut, setidak-tidaknya sepanjang yang berkenaan dengan bahagian harta peninggalan yang tidak berwujud harta adat (terutama tanah-tanah adat yang diwarisi para leluhur). Ada keinginan agar dalam harta pencaharian orang tua, anak-anak perempuan diberi hak untuk ikut serta mewarisi disamping saudara laki-lakinya meskipun dalam porsi yang kecil. Keingian ini bukan saja dicetuskan oleh pewaris (orang tua). Apakah dari adanya gejala ini dapat disimpulkan bahwa telah ada pergeseran kesadaran hukum waris ke arah yang membuka pintu emansipasi wanita, sampai ke bidang hukum waris adat $?^{46}$

Kaitannya dengan janda, sepanjang informasi yang penulis terima, hampir tidak ada satu pun upaya yang dapat dilakukan untuk menempatkan janda sebagai ahli waris dalam makna yang sebenarnya. Kematian yang tidak dapat diterjemahkan sebagai sebuah perceraian ${ }^{47}$ pada satu sisi merupakan sebuah keuntungan bagi istri. Ia masih menjadi bagian dari keluarga suaminya. Oleh sebab itu, kematian suaminya tidak merubah apapun kecuali ia tidak lagi mempunyai suami. Haknya terhadap rumah dan anak-anaknya tidak berubah sama sekali. Namun, ia tetap tidak memiliki bagian dari harta suaminya. Ia hanya berhak memanfaatkan harta tersebut sebatas keperluannya selama hidup. Alih-alih untuk memperoleh harta bersama, janda sama sekali tidak memperoleh harta waris dalam makna khusus sebagai harta yang dapat dimiliki dan dikuasai sepenuhnya. Sepanjang tidak terjadi "perceraian" mungkin tidak menjadi masalah. Ibu akan mencurahkan dan mendayagunakan harta bendanya untuk anak-anaknya. Akan tetapi bagaimana jika terjadi perceraian ? Sampai di sini perempuan hanya berhak membawa harta asalnya. Ketentuan tersebut sangat berbeda dengan aturan yang terdapat di dalam hukum Islam. Ketika terjadi kematian, maka perceraian secara otomatis telah terjadi dan istri (janda) disamping mendapatkan harta waris juga memperoleh harta bersama. ${ }^{48}$

Penulis ingin mengatakan bahwa hukum adat Karo sebenarnya bergerak mendekati hukum Islam. Apapun yang diterima perempuan Karo, apakah melalui pemberian saudara laki-lakinya, pemberian (hibah) orang tuanya (harta buat-buaten), atau melalui wasiat, semuanya dimaksudkan agar perempuan Karo

${ }^{46}$ M. U. Sembiring, "Hukum Adat Karo dalam Rangka Perubahan Sosial”, dalam Sarjani (ed.), Bunga Rampai Seminar Kebudayaan Karo dan kehidupan Masa Kini, (T.T.t.: Kabanjahe, 1985) h. 111-112.

${ }^{47}$ Bandingkan dengan konsep perceraian yang ada di dalam hukum Islam dan hukum perdata.

${ }^{48}$ Lihat pasal-pasal dalam Kompilasi Hukum Islam khususnya Bab XIII pasal 85-97. Di antara pasal yang cukup penting adalah pasal 96 ayat 1 yang isinya, "Apabila terjadi cerai mati, maka separoh harta bersama menjadi hak pasangan yang hidup lebih lama". Adapun ayat (2) adalah "Pembagian harta bersama bagi seorang suami atau istri yang istri atau suaminya hilang harus ditangguhkan sampai adanya kepastian matinya yang hakiki atau matinya secara hukum atas dasar putusan pengadilan agama. Selanjutnya pada pasal 97 yang isinya, "Janda atau duda cerai hidup masing-masing berhak seperdua dari harta bersama sepanjang tidak ditentukan lain dalam perjanjian perkawinan". 
dapat menikmati harta waris orang tuanya. Tegasnya, perempuan Karo juga mendapatkan harta waris orang tuanya sebagaimana yang berlaku di dalam hukum Islam. Tentu tidak persis sama dengan apa yang berlaku di dalam hukum waris Islam seperti pola 2:1 tersebut.

Hukum waris adat Karo saat ini sedang bergerak menuju bentuk baru sebagaimana yang telah ditunjukkan pada kajian-kajian terdahulu merupakan sebuah realita. Pergerakan itu, menurut penulis, adalah hukum waris adat Karo sedang mendekat pada hukum Islam.

\section{Penutup}

Uraian di atas menunjukkan bahwa masyarakat Karo Muslim masih menggunakan hukum adat dalam menyelesaikan pembagian harta warisan. Kendati demikian, beberapa dekade terakhir telah muncul kesadaran baru di kalangan masyarakat Karo Muslim untuk lebih memperhatikan anak perempuan atau saudara perempuannya. Fenomena yang tidak kalah menariknya adalah banyak orang tua telah menggunakan instrumen hukum lain untuk memberikan harta waris dalam bentuk harta bergerak (emas dan uang) kepada anak perempuannya. Inilah yang disebut dengan strategi memberikan akses harta waris kepada anak perempuan. Wasiat dan hibah adalah pilihan yang digunakan orang tua. Tidaklah mengherankan jika banyak orang tua semasa hidupnya telah mendistribusikan sebagian harta bergerak kepada anak perempuannya.

Cara lain adalah dengan memberi kesempatan yang seluas-luasnya kepada anak perempuan untuk menempuh pendidikan setinggi-tingginya dan juga fasilitas untuk mencari pekerjaan yang laik. Upaya ini dapat dipandang sebagai strategi untuk membuat anak perempuan lebih mandiri sehingga tidak tergantung kepada saudara laki-lakinya. Umumnya gejala ini dalam beberapa studi tentang harta waris disebut dengan fenomena "individualisasi". Terhadap harta tidak bergerak, seperti sawah atau lading, individualisasi dilakukan dengan investasi modal, misalnya untuk perkebunan atau pertanian. Sedangkan terhadap anak perempuan, individualisasi dilakukan dengan memberi kesempatan yang seluas-luasanya untuk sekolah sampai akhirnya memperoleh pendidikan yang tinggi dan pekerjaan yang laik.

Adapun yang berkaitan dengan hak waris janda hampir tidak ada perubahan yang signifikan. Namun jika dicermati secara seksama, pergeseran hak waris janda sebenarnya sedang berlangsung secara perlahan, khusunya bagi janda-janda yang memiliki kemandirian ekonomi. Wanita yang mandiri relatif lebih memiliki keleluasaan untuk mengelola harta peninggalan suaminya. Kendatipun secara eksplisit tidak ada pembagian tentang harta bersama dan bagian waris tertentu, namun secara substansi, penguasaan terhadap harta peninggalan suami menunjukkan semakin menguatnya hak-hak istri terhadap harta suaminya.

Kecenderungan-kecenderungan tersebut menunjukkan bahwa hukum adat Karo dalam hal warisan sebenarnya sedang bergerak. Hukum adat Karo sangat dinamis. Kesimpulan yang terpenting adalah hukum waris adat Karo yang berbasis patrilineal sesungguhnya sedang bergerak ke arah hukum waris yang berbasis bilateral. Agaknya fenomena ini semakin meyakinkan kita bahwa hukum waris nasional akan segera terwujud pada saat hukum waris yang berbasis patrilineal dan matrilineal bergerak ke arah bilateral. Harus diyakini bahwa pergerakan itu sesungguhnya saat ini sedang berlangsung. []

\section{Pustaka Acuan:}

Abdullah, Irwan, Seks, Gender \& Reproduksi Kekuasaan, Yogyakarta: Tarawang, 2001.

Abu Bakar, Al Yasa, Ahli Waris Sepertalian Darah: Kajian Perbandingan terhadap Penalaran Hazairin dan Penalaran Fikih Mazhab, Jakarta: INIS,1998.

Astiti, Tjok Istri Putra, "Hak-Hak Wanita Bali dalam Hukum Adat Waris", dalam E.K.M. Masinambaow (ed.), Hukum dan Kemajemukan Budaya: Sumbangan Karangan untuk Menyambut Ulang Tahun ke-70 Prof. Dr.O. Ihromi, Jakarta: Obor, 2000.

Ball, John, Indonesian Law at the Crossroads: Commentary and Materials, Sydeny: Oughtershaw, 1996.

Bangun, Tridah, Penulisan dan Pencatatan Adat Istiadat Karo, Jakarta: Yayasan Merga Silima, 1990.

Beckmann, Franz Von Benda, Properti dan Kesinambungan Sosial, diterjemahkan oleh Tim Perwakilan KITLV dan Indira Simbolon, Jakarta: Grasindo, 2000.

Bowen, John, Islam, Law, and Equality in Indonesia: An Anthropolgy of Public Reasoning, London: Cambridge University Press, 2003.

Cuth, Nursal, Kamus Sosiologi dan Antropologi, Jakarta: Galaxy Puspa Mega, 1992.

Darwin, Muhadjir dan Tukiran, Menggugat Budaya Patriarki, Yogyakarta: Pusat Penulisan Kependudukan Universitas Gajah Mada dan Ford Foundation, 2006.

Departemen Pendidikan dan Kebudayaan, Kamus Besar Bahasa Indonesia, Jakarta: Balai Pustaka, 1995, Cet.V, Edisi II.

Haar, Ter, Asas-Asas dan Susunan Hukum Adat, Djakarta: 
Pradnya Paramita, 1991.

Hadikusuma, Hilman, Hukum Waris Adat, Bandung: Alumni, 2003.

Hazairin, Hukum Kewarisan Bilateral Menurut Qur'an dan Hadith, Jakarta: Tintamas, 1990, Cet: VII.

Khalil Abdul Karim, Syariah: Sejarah Perkelahian Pemaknaan, diterjemahkan oleh Kamran As'ad, Yogyakarta: LkiS, 2003.

Khan, Muhammad Mustafa, Islamic Law of Inheritance: A New Approach, New Delhi: Kitab Bhavan, 2005, Cet. III.

Lukito, Ratno, "Pergumulan Hukum Islam dan Adat di Indonesia", dalam Dody S. Truna dan Ismatu Ropi (penyunting), Pranata Islam di Indonesia: Pergulatan Sosial, Politik, Hukum, dan Pendidikan, Jakarta: Logos, 2002.

Manan, Abdul, Aneka Masalah Hukum Perdata Islam di Indonesia, Jakarta: Kencana Prenada, 2008.

Meliala, Djaja S. dan Aswin Peranginangin, Hukum Perdata Adat Karo dalam Rangka Pembentukan Hukum Nasional, Bandung: Tarsito,1979.

Muhammad, Bushar, Asas-Asas Hukum Adat: Suatu Pengantar, Jakarta: Pradnya Paramita, 2006.

Prints, Darwins, Adat Karo, Medan: Bina Media Perintis, 2004.

Sembiring, H.K.Kueteh, "Perkembangan Hukum Adat Etnis Batak Dalam Pembagian Harta Warisan", Laporan Penulisan Fakultas Hukum Universitas Sumatera Utara, 1990.

Sembiring, M. U., "Hukum Adat Karo dalam Rangka Perubahan Sosial", dalam Sarjani (ed.), Bunga Rampai Seminar Kebudayaan Karo dan kehidupan Masa Kini, T.T.t.: Kabanjahe, 1985.

Shâbûnî, al-, Muhammad 'Alî, Al-Mawârits fîal-Syarîa'h al-Islâmiyyah fì Dhaw'I al-Kitâb wa al-Sunnah, Madinah: Dâr al- Shâbûnî, 2002.
Siddik, Abdullah, Hukum Adat Rejang, Jakarta: Balai Pustakan, 1977.

Sitorus, Felix, "Hak Waris Janda dan Anak Perempuan Batak", dalam Hukum dan Kemajemukan Budaya, editor E.K.M.Masinambow, Jakarta: Yayasan Obor Indonesia, 2000.

Slaats, Herman dan Karen Portier, Traditional Decision Making and Law, Yogyakarta: Gadjah Mada University Press, 1992.

Soekanto, Meninjau Hukum Adat Indonesia: Suatu Pengantar untuk Mempelajari Hukum Adat, Jakarta: Rajagarfindio 1996.

Soemadiningrat, Otje Salman, Rekonseptualisasi Hukum Adat Kontemporer, Bandung: Alumni,2002.

Subekti, R. dan J. Tamara, Kumpulan Putusan Mabkamah Agung Mengenai Hukum Adat, Djakarta: Gunung Agung, 1965.

Subekti, R., Hukum Adat Indonesia dalam Yurispridensi Mahkamah Agung, Bandung: Alumni, 1991.

Syarifuddin, Amir, Hukum Kewarisan Islam, Jakarta:Prenada Media, 2004.

-------, Pelaksanaan Hukum Kewarisan Islam dalam Lingkungan Adat Minangkabau, Jakarta: Gunung Agung, 1982.

Tamboen, P., Adat Istiadat Karo, Djakarta: Balai Pustaka, 1952.

Thalib, Sajuti, Hukum Kewarisan Islam di Indonesia, Jakarta: Sinar Grafika, 2008, Cet. VIII.

Vergouwen, J.C., Masyarakat dan Hukum Adat Batak Toba, Yogyakarta: LKiS, 2004.

Yaswirman, Hukum Keluarga Adat dan Islam: Analisis Sejarah, Karakteristik, dan Prospeknya dalam Masyarakat Matrilineal Minangkabau, Padang: Andalas University Press, 2006. 